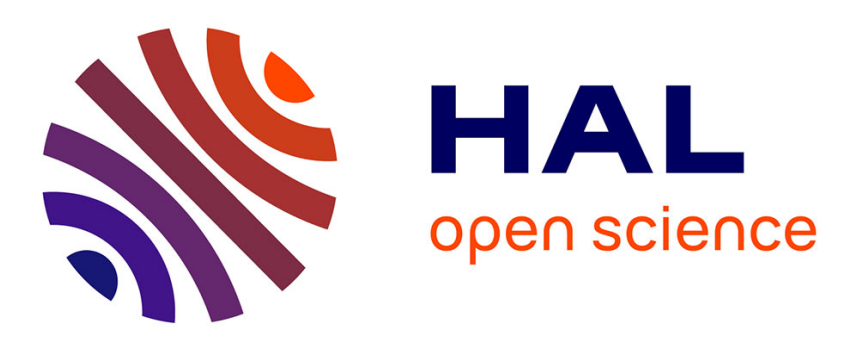

\title{
The role of sectoral FDI in promoting agricultural production and improving food security
}

Mehdi Ben Slimane, Marilyne Huchet, Habib Zitouna

\section{To cite this version:}

Mehdi Ben Slimane, Marilyne Huchet, Habib Zitouna. The role of sectoral FDI in promoting agricultural production and improving food security. 2015, 145 (May 2016), pp.34. hal-01169624

\section{HAL Id: hal-01169624 \\ https://hal.science/hal-01169624}

Submitted on 29 Jun 2015

HAL is a multi-disciplinary open access archive for the deposit and dissemination of scientific research documents, whether they are published or not. The documents may come from teaching and research institutions in France or abroad, or from public or private research centers.
L'archive ouverte pluridisciplinaire HAL, est destinée au dépôt et à la diffusion de documents scientifiques de niveau recherche, publiés ou non, émanant des établissements d'enseignement et de recherche français ou étrangers, des laboratoires publics ou privés. 


\section{Author's Accepted Manuscript}

The role of sectoral FDI in promoting agricultural production and improving food security

Mehdi BEN SLIMANE, Marilyne HUCHETBOURDON, Habib ZITOUNA

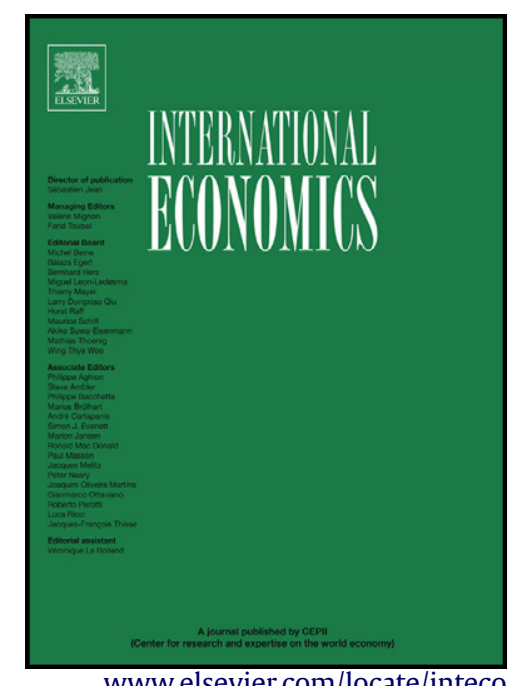

www.elsevier.com/locate/inteco

PII:

S2110-7017(15)00049-9

DOI: http://dx.doi.org/10.1016/j.inteco.2015.06.001

Reference: INTECO74

To appear in: International Economics

Cite this article as: Mehdi BEN SLIMANE, Marilyne HUCHET-BOURDON, Habib ZITOUNA, The role of sectoral FDI in promoting agricultural production and improving food security, International Economics, http://dx.doi.org/10.1016/j. inteco.2015.06.001

This is a PDF file of an unedited manuscript that has been accepted for publication. As a service to our customers we are providing this early version of the manuscript. The manuscript will undergo copyediting, typesetting, and review of the resulting galley proof before it is published in its final citable form. Please note that during the production process errors may be discovered which could affect the content, and all legal disclaimers that apply to the journal pertain. 
The role of sectoral FDI in promoting agricultural production and improving food security

Mehdi BEN SLIMANE, IHEC Carthage, UR MASE and AGROCAMPUS OUEST UMR 1302, France

38, Street Elboukri, Mourouj 5 Ben Arous-2074 Tunisia

E-mail: benslimane.mehdi87@gmail.com

Marilyne HUCHET-BOURDON, AGROCAMPUS OUEST- INRA, UMR1302, F-35000 Rennes, France

65 rue de St Brieuc, CS 84215, F-35042 Rennes Cedex- France

E-mail: marilyne.huchet-bourdon@agrocampus-ouest.fr

Habib ZITOUNA, University of Carthage, UR MASE

Faculté des Sciences Economiques et de Gestion de Nabeul

Campus universitaire Mrezga

Route Hammamet

8000, Nabeul, Tunisia

E-mail: hzitouna@gmail.com

Corresponding Author:

Mehdi BEN SLIMANE

Address: 38, Street Elboukri, Mourouj 5 Ben Arous-2074

Tunisia.

Phone in Tunisia: +21621642021

Phone in France: $+33(0) 785686253$

Email: benslimane.mehdi87@gmail.com 


\begin{abstract}
:
The aim of this paper is to examine the effects of foreign direct investments (FDI) on food security for 55 developing countries in a panel framework over the period 1995-2009. There are various measures of food security that can be used. Our first contribution is to build a composite indicator that synthesizes the food indicators used by the Food and Agriculture Organization to measure the food availability and food utilization. Second, our empirical study is based on a model composed of a food security equation and an agricultural production equation. Our results show that sectoral FDI have different effects on food security. FDI in the agriculture sector improves food security and FDI in the secondary and tertiary sector increases the food insecurity. We found a significant FDI's spillover through the agricultural production to food security. While the effect is positive with FDI in secondary sector, it is negative for FDI in the tertiary sector.
\end{abstract}

Keywords: Food security; FDI; agricultural production; developing countries.

JEL classifications: F1, Q1 


\section{Introduction}

Food security is a big challenge to the economic decision-makers in developing countries (DCs) and it is closely linked to social stability in these areas, where poverty can reach very high levels. According to the State of Food Insecurity in the World's report of Food and Agriculture Organization (FAO), World Food Programme (WFP) and the International Fund for Agricultural Development (IFAD) (2013), nearly 842.3 million people (12\% of the world population) are chronically undernourished; the vast majority lives in developing countries.

The economic and social potential of developing countries does not necessarily lead to good results in improving food security. In fact, it faces to a global economic context, which is characterized by changes in growth, commodity prices, climate and trade. The World Bank (2008) as well as he FAO, WFP and IFAD (2012) show that agricultural investment plays an important role in promoting agricultural growth, reducing poverty and hunger. Liu (2014) summarizes the results of FAO's case studies on the impacts of foreign agricultural investment on host communities and countries. ${ }^{1}$

The recourse to the attraction of foreign direct investments (FDI) can be an alternative for developing countries. The FDI inflows have grown greatly in these countries, from $16.7 \%$ of global inflows in the early 1990 s to $52 \%$ in 2012. Among them, the lowest share is directed to Africa and the biggest share is directed to the East and the Southeast of Asia (UNCTAD, 2013).

According to these stylized facts, a positive relationship between FDI inflows and the food supply is expected. In fact, the empirical literature dealing with the impact of FDI on food security dates back to the 1980s. The focus was on the distinction between the dependency and the modernization effects. Indeed, foreign investments could play a positive role via their 
effect on agricultural productivity (Hallam, 2011) but they are also a source of economic and political dependency (Jenkins and Scanlan, 2001; Wimberley, 1991). As far as we know, a number of empirical studies have used the aggregated FDI inflows (see Wimberley, 1991; Firebaugh, 1992; Firebaugh and Beck, 1994; Jenkins and Scanlan, 2001). The sectoral approach of FDI is rarely used and when it is, it concerns rather developed countries. In addition, the spillover effect of FDI has been seeing in intra-industry rather than in interindustry ( $\mathrm{Vu}$ and Noy, 2009). So, there is a lack in the literature about this relation when we are focusing on sectoral FDI in developing countries. Another limit in the existing empirical works is the neglect of agricultural production, which is the main base of food security.

To our best knowledge, at disaggregated level, only Mihalache-O'Keef and Li (2011) analyzed the direct economic relationship between sectoral FDI and food security in a large sample. Djokoto (2012) investigated the effects of FDI on food security in one particular developing country, Ghana. On the other hand, a large economic literature deals with FDI spillovers. At the sectoral level, we could cite a recent work of Tondl and Fornero (2010) that examined the relationship between FDI and productivity in different economic sectors.

There is no study addressing the transmission channels between FDI and food security, especially through agricultural production channel. This paper tries to fill in this gap. Our contribution is at least twofold. First due to different measures of food security and consequently to a number of criticisms like the possible different typology of countries associated with each measure, we propose a composite indicator of food security ${ }^{2}$. Second, we try to determine the channels by which FDI may affect food security, focusing on the agricultural production. We propose to answer the following questions: Does FDI has a positive impact on food security? Is agricultural production a pass-through from FDI to food security? Is this effect observed for all FDI or only FDI in specific sectors? 
To answer these questions we rely on two equations, one for the macroeconomic determinants of food security and the other for the agricultural production determinants. These equations are linked by a simultaneous equation system and tested through three steps least square techniques (3SLS) for an unbalanced panel of 55 developing countries during the period 1995-2009. Our work confirms that the sectoral FDI do not all have the same effects, which supports the argument of Vu and Noy (2009) to use the sectoral FDI rather at its aggregated level.

In this perspective, our work is organized as follows. In the next section, a review of literature is proposed. Section 3 describes the data and the methodology we adopted. The results are then discussed in section 4 and section 5 concludes.

\section{Review of literature}

Agriculture is a pivotal crucial sector for developing countries: it represents an important weight in the developing countries' economy. One of the best ways to prevent food crises in the long-run is to invest in agricultural productivity. Indeed, improving agricultural productivity is an important step towards the growth of food production, the reduction in food prices on local markets and the increase in farm income, which improves the poors' access to food. Productivity is sensitive to the state of health of the population (Timmer, 2010). In fact, hunger affects the health and leads to reduced productivity of people. According to FAO (2006a), this problem hinders economic development and the potential of entire societies. In later publication, the FAO (2009) showed the important role of the agricultural sector in developing countries and especially poor ones. It can be a buffer to the economic and employment during periods of crisis. 
Our work is at the crossroads of three fields of the literature, the relationship between FDI and food security, FDI and agricultural production, and food security and agricultural production as represented by the Figure 1 .

Figure 1: The relationships between FDI and food security

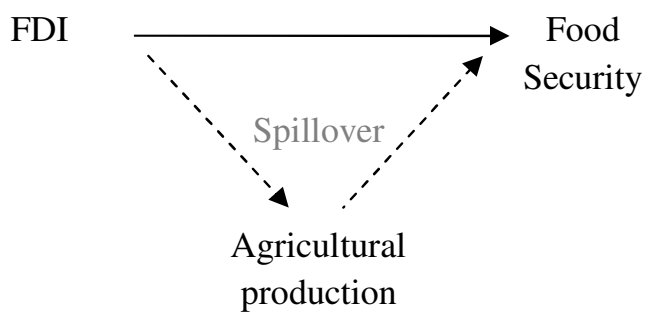

From these relations, we seek the two effects of FDI on food security. The first effect is determined by testing the effect of FDI on the food security directly and the indirect effect is determined by spillover of FDI on agricultural production, the latter being important in the improvement of food security. But first of all, we must remind the food security's concept and measurement.

\subsection{Food Security: Concept and measurements}

Food security is an old concept which was born in the mid-1970s at the world food summit in 1974. In the mid-1980s, food security was defined by the World Bank (1986) "as access by all people at all times to enough food for an active, healthy life". This definition has evolved over the years. In 1996, the World Food Summit defined the food security in its declaration by: "Food security exists when all people, at all times, have physical and economic access to sufficient, safe and nutritious food that meets their dietary needs and food preferences for an active and healthy life" (FAO, 2006b).

The FAO identified four dimensions for food security. First, the food availability is "the availability of sufficient quantities of food of appropriate quality, supplied through domestic production or imports". Second, the food access is "the access by individuals to adequate 
resources (entitlements) for acquiring appropriate foods for a nutritious diet". Third, the food use is the "utilization of food through adequate diet, clean water, sanitation and health care to reach a state of nutritional well-being where all physiological needs are met". Finally, the food stability or food secure is "a population, household, or individual who must have access to adequate food at all times. They should not risk losing access to food as a consequence of sudden shocks (e.g. an economic or climatic crisis) or cyclical events (e.g. seasonal food insecurity)".

Food security is measured by several indicators related to nutrition and hunger as the per capita per day intake of calories, protein and fat. These indicators allow the follow-up of the food situation of a country. The FAO and the World Health Organization (WHO) measure undernutrition of the individuals by energy requirements in terms of caloric intake, protein intake and fat intake. These requirements constitute the essential nutritive elements in food. Several empirical studies have used the per capita per day calories and protein intake as an indicator of food security like Wimberley (1991), Wimberley and Bello (1992), Firebaugh and Beck (1994), Mihalache-O'Keef and Li (2011) and Djokoto (2012).

The literature also shows several indicators like the ratio of total exports to food imports (Díaz-Bonilla et al., 2000). This indicator is commonly used to measure the macro-level of food security. It enables to know whether a country can achieve food security by generating foreign exchange through exports, which could allow financing food imports. In a descriptive analysis, Breisinger et al. (2010) used the inverse of this traditional index to test the vulnerability of the country to secure food import. This indicator is considered by the FAO as an indicator of food stability. Authors have also used other indicators, like food production per capita to assess the agricultural potential, and hunger index to evaluate the famine.

There are also the Millennium Development Goals (MDGs) that present eight goals which the poverty's eradication is one of it (United Nation, 2000). In this context, Gentilini and Webb 
(2008) proposed a composite indicator labeled the poverty and hunger index. It is a multidimensional index that combines five official indicators of the MDGs: the proportion of population living on less than US $\$ 1 /$ day, the poverty gap ratio, the share of the poorest quintile in national income or consumption, the prevalence of underweight children (under five years of age) and the proportion of population undernourished.

There are many other indicators of food security discussed in the literature (see DeHaen et al. (2011), Masset (2011)). Some of them are linked to the four pillars of food security and others are from the Millennium Development Goals. This diversity of indicators justifies the complexity of food security's concept. At the empirical level, it is preferable to contain this diversity by the construction of our composite indicator that must be in harmony with the focus of the paper. This composite indicator, as described below in section 3, relies on four indicators used by the FAO and is based on Principal Component Analysis Techniques.

\subsection{FDI and Food security}

In the early 1980s, studies on the relationship between FDI inflows and food security have emerged. The focus was on two contradictory theories: the dependency theory and the modernization theory.

The post-World War II period was characterized by large FDI inflows to DCs, specifically into the extractive sector. In fact, the multinational corporations (MNCs) were on the research of natural resource, cheap labor, and profit. So they penetrated into the most dynamic sectors in DCs, and in consequence, leads the host countries towards improper development (Amirahmadi and $\mathrm{Wu}, 1994)$.

Accordingly to this theory, the FDI's effects are potentially destructive, if the MNCs manipulate the prices of goods to avoid taxes, repatriate profit to origin country, influence local politics and economic conditions by controlling the means of production, in addition to 
adverse effect on growth and the distribution of income (Dixon and Boswell, 1996; Heo and Hahm, 2007; Adams, 2009). In this regard, the dependency on foreign investment has negative effects on DCs.

Supporters of the modernization theory focus on internal and external sources of economic development. Internal sources come from domestic investment, growth and education by creating industrialization and cultural modernization, and finally provide social welfare (Jenkins and Scanlan, 2001). External sources come from FDIs, which bring technology, organizational capability, management skills and marketing know-how. FDI inflows provide easy access to international markets and diffuse new skills and knowledge in the host economy (Kumar and Pradhan, 2002). The technology transfer and know-how lead to productivity gains and improved efficiency of allocation of resources (Graham, 1995; Tambunan, 2005). But the technology transfer has also some adverse effects. On one side, its learning processes is costly. On the other side, the managerial and technical capacities and the ability to finance the adoption of advanced technology are not the same across local firms (Liu, 2008). The adverse effect is found in Zambia when the presence of foreign firms has reduced the productivity of local firms (Bwalya, 2006).

Both theories have been adopted to explain the impact of foreign investments on welfare. A selected list of papers dealing with the relationship between FDI and food security is provided in Table 1. 
Table 1: Selected empirical findings on FDI-food security nexus

\begin{tabular}{|l|c|c|c|c|}
\hline \multicolumn{1}{|c|}{ Authors } & $\begin{array}{c}\text { Countries } \\
\text { Period }\end{array}$ & Methodology & Type of FDI data & $\begin{array}{c}\text { Empirical } \\
\text { results }\end{array}$ \\
\hline Wimberley (1991) & $\begin{array}{c}60 \mathrm{DCs} \\
1967-1985\end{array}$ & Lagged panel & $\begin{array}{c}\text { Penetration of } \\
\text { transnational } \\
\text { corporations }\end{array}$ & $(-)$ \\
\hline Wimberley and Bello (1992) & $\begin{array}{c}59 \mathrm{DCs} \\
1967-1985\end{array}$ & Lagged panel & $\begin{array}{c}\text { Penetration of } \\
\text { transnational } \\
\text { corporations }\end{array}$ & $(-)$ \\
\hline Firebaugh and Beck (1994) & $\begin{array}{c}62 \mathrm{DCs} \\
1965-1985\end{array}$ & $\begin{array}{c}\text { - Difference-of-logs model } \\
\text { - Difference model }\end{array}$ & $\begin{array}{c}\text { FDI stock as share of } \\
\text { GDP }\end{array}$ & $\begin{array}{c}(+) \\
(-)\end{array}$ \\
\hline Jenkins and Scanlan (2001) & $\begin{array}{c}88 \mathrm{DCs} \\
1970-1990\end{array}$ & Lagged panel & $\begin{array}{c}\text { FDI stock over total } \\
\text { capital stock ratio }\end{array}$ & $(-)$ \\
\hline Mihalache-O'Keef and Li (2011) & $\begin{array}{c}56 \mathrm{DCs} \\
1981-2001\end{array}$ & $\begin{array}{c}\text { - Lagged panel } \\
\text { - Simultaneous equations }\end{array}$ & $\begin{array}{c}\text { - Primary FDI; } \\
\text { - Secondary FDI } \\
\text { - Tertiary FDI }\end{array}$ & $\begin{array}{c}(-) \\
(+) \\
(+) \text { and (-) }\end{array}$ \\
\hline Djokoto (2012) & Ghana & ARDL Model & Agricultural FDI & $(-)$ \\
\hline
\end{tabular}

Note: (-) and (+) are negative and positive effect respectively.

Theoretically, primary FDI affects food security negatively due to the increase in unemployment, changes in the use of agricultural land, and negative environment and demographic externalities. In contrast, FDI in the secondary sector improve food security by raising employment and wages, technology and knowledge spillovers. However, tertiary FDI has an ambiguous impact partitioned between unskilled and skilled labor. According to Todaro (1969), Evans and Timberlake (1980) and Mihalache-O'Keef and Li (2011), the unskilled labor is affected by tertiary FDI when this latter spurs rural labors to migrate to urban slums for jobs with high incomes, thus subsistence agriculture declines, and therefore migrants pay higher prices on urban markets which reduce their access to food. However, the skilled labor is affected by tertiary FDI flows when the latter improve the individual income, which is favorable to the satisfaction of basic nutritional needs.

\subsection{FDI and agricultural production}

The literature review suggests that the impact of FDI in the agricultural sector can be positive or negative. Some case studies show the FDI's positive side. For instance, in Ghana, the investments by one transnational company contributed to an increase in total production of 
palm oil and in Uganda, companies such as Tilda (U) Ltd contributed to the growth of rice production, which has almost doubled in the last decade after the introduction of a new variety of rice called Nerica (Gerlach and Liu, 2010). In terms of positive spillovers, the example of Poland is the most appropriate to be cited here, where the vertical and horizontal FDI inflows have positively affected the dairy sector (Dries and Swinnen, 2004). Moreover, spillovers in terms of technology transfers and know-how have improved agriculture production in Ghana (Djokoto, 2012). In fact, the technology transfers can lead to greater domestic productivity, increase in production and employment in addition to a reduction in domestic prices, but this can have both negative and positive environmental effects (Hallam, 2011). In this context, the Uganda's government has adopted friendly production methods to the environment, i.e. investment in floriculture (Gerlach and Liu, 2010). Empirically, the pollution-haven argument can be put forward to explain the potential negative effect of FDI on the environment and households' health. FDI damage the environment, especially when the activity is in the mining industry. For instance, according to Akabzaa and Darimani (2001), the mining industry has weakened and polluted the water table in the Tarkwa mining region in Ghana and this pollution has affected the households' health.

At the sectoral level of FDI, very few works exist on this topic. The sectoral level reveals two directions of the FDI effects. First, the effect is direct from agriculture FDI to agricultural production. Second, the effect is indirect from spillovers of FDI in the rest of economic sectors to agricultural production. This can be seen in the case of Latin America where FDI in agriculture has a positive and significant effect on agricultural productivity and a positive spillover effect from manufacturing FDI and services FDI. The indirect effects may be explained by the presence of foreign capital in agri-food industries, which requires more efficiency in agricultural production. Regarding the spillover effect from FDI in services, the 
agricultural sector can be beneficial by enhanced productivity in the transport sector (Tondl and Fornero, 2010).

To our best knowledge, there is no study that analyzes the link between sectoral FDI and the agricultural production. However, the use of food security indicators on explaining the effect of nutrition on farm productivity was tested by Strauss (1986) and Deolalikar (1988). The first used a household-level data from Sierra Leone and he found that nutrient intake has increased the productivity of agricultural labor. Deolalikar (1988) found practically the same results in a sample from the rural south of India. He found that the average daily calorie intake and the weight-for-heigh lead to improve the agricultural production's growth.

To conclude the literature review, the theory is in favor of a relationship between foreign direct investment and food security, but according to the empirical analysis, there is a lack of evidence on the way FDI may influence food security, in particular at disaggregated level.

\section{Data and Methodology}

\subsection{Data}

This work is based on an unbalanced panel of 55 developing countries (see Table A1 in the appendix) over the period 1995-2009. Tables A2 and Table A3 in the Appendix report the definitions and the descriptive statistics. Most of the data were extracted from the Word Development Indicators database of the World Bank. Other data are collected from UNCTAD, FAOSTAT, Polity IV and national sources.

First of all, a correlation analysis is performed between all variables (Table A4 in the Appendix). We observe that the correlation is low between variables, but it is high between the values of agricultural production, capital stock and labor force in agriculture and the arable land. This high correlation reflects the combination between these variables to achieve the production process. 
Different measures of food security were proposed by FAO. The most known one is the per capita per day supply of calories. According to the FAO, this indicator referred to the total amount of food available per day for human consumption divided by the total of population during the reference period. This indicator is used in some empirical works to measure the nutritional status of individuals and to present the food availability, but the literature reveals that this indicator has several weaknesses due to the low responsiveness to shocks. For example, the decrease of income leads poor people to switch from high value calorie sources to low ones. Consequently, the food expenditure decreases but not the calorie consumption (Jensen and Miller 2010; Headey and Ecker 2012). The calorie intake is used in some works like Mihalache-O'Keef and Li (2011). The same authors have used also the protein intake as an indicator to compare results with the calorie intake's results. There is no utility to use these two indicators because the calories are a measure of the energy provided by proteins, fats and some others nutrients ${ }^{3}$. Otherwise, the calorie intake includes more information about the nutritional status than protein intake. Additionally, the calories alone are not enough to describe the food availability. To deal with the weakness of calories we have chosen the most important indicators from FAOSTAT, which are linked to the agricultural production and food supply. First, we have chosen the average dietary energy supply adequacy as an indicator of adequacy of the food supply in terms of calories. It is calculated as a percentage of the average dietary energy requirement. Second, the average value of food production per capita provides a measure of the economic size of the food production sector and the food availability for everyone in a country. These two indicators describe the first pillar of food security, food availability, and they are calculated on three years averages by FAO to correct errors in the measure. Third, we consider the access to improved water sources, which is the percentage of the population with an access to an adequate amount of water. Finally, the access to improved sanitation facilities is taken into account; it is expressed by the percentage 
of the population with at least adequate access to good sanitation. This choice is justified by the fact that people need to utilize food properly to avoid health issues, for example intestinal parasites from unsanitary water (Tweeten, 1999). In addition, the access to water is essential for agriculture and food, and the improved sanitation reduces the pollution caused by human waste. Taken separately, the four indicators mentioned provide a fragmented and sometimes contradictory picture: they tell little about net progress towards reaching the overall goal. A composite index can assemble the information provided by individual measures.

Our analysis will also shed light on the importance of sectoral FDI inflows presented by (i) FDI in agriculture, hunting, forestry and fishing (ii) FDI in mining, quarrying and oil and gas extraction ${ }^{4}$, (iii) FDI in the secondary sector and ${ }^{5}$ (iv) FDI in the tertiary sector in addition to other factors such as economic development, government expenditure, agricultural production, trade openness, political regime.

The economic development is measured by GDP per capita: we expect a positive effect from this variable (Wimberley and Bello, 1992; Jenkins and Scanlan, 2001; Mihalache-O'Keef and $\mathrm{Li}, 2011)$. The government expenditure is measured by the annual growth of the general government final consumption expenditure. This variable is to control the government's role to address food security concerns and a positive impact is expected.

To test for the impact of trade openness, we use the sum of exports and imports of goods and services as a share of GDP. We attend to find a positive impact from trade openness on food security because imports provide the needed complement if the domestic food production is not sufficient (Diaz-Bonilla et al., 2000; 2003). In addition, the exports generate foreign exchange revenues used to import food.

The political regime is measured by POLITY2 indicator. This indicator is a modified version of POLITY which varies between 10 (highly democratic) and -10 (very autocratic) ${ }^{6}$. In fact, democratic governments are more likely to provide nutrition to their people than the less 
democratic or autocratic countries (Sen, 1999; Mihalache-O'Keef and Li, 2011). We finally consider the value of agricultural production. The main determinants are capital, labor and land. They are measured respectively by the stock of capital in agriculture, the labor force in agriculture and the area of arable land. We have added the rural population growth as a measure of the population structure to examine if the rural population growth improves the agricultural production. We expect a positive effect on agricultural production as found by Binswanger et al, (1987) that an increase in population density leads to agricultural growth.

\subsection{Methodology}

First, we build a composite indicator for food security. Then we specify the equation of macroeconomic determinant of food security and the equation of agricultural production.

\subsubsection{Construction of a composite index for food security}

In this paper, four indicators of food security are used to build a composite indicator using the principal component analysis (PCA). The indicators are the average dietary energy supply adequacy, the average value of food production per capita, access to improved water sources and access to improved sanitation facilities. The objective of the PCA method is to reduce the number of indicators by the transformation of a set of correlated variables into a new set of uncorrelated variables entitled principal components ${ }^{7}$. The method consists in the capture of the maximum variance between variables, which gives for every principal component a linear transformation as follow:

$$
P C^{p}=\delta_{1}^{p} X_{1}^{p}+\delta_{2}^{p} X_{2}^{p}+\cdots+\delta_{n}^{p} X_{n}^{p}
$$

With, $P C^{p}$ is the $P$ th principal component. $X_{n}^{p}$ is the value of the $n$th variable for the $P$ th component and $\delta_{n}^{p}$ is the regression coefficient for the $n$th variable of the $P$ th component and it is the eigenvector of the covariance matrix between the variables. 
Return to our data, there is a high correlation between our four indicators (see Table 2), so the PCA method can be used here. The literature of PCA method reveals many extensions to this method. One of the extensions is the correction of outling in the data. We believe that the four indicators are different between DCs and to avoid this problem we followed the methodology of Verardi (2009) to do a robust analysis of the principal component.

Table 2: Correlation test between the food security indicators

\begin{tabular}{|l|c|c|c|c|}
\cline { 2 - 5 } \multicolumn{1}{c|}{} & $(1)$ & $(2)$ & (3) & (4) \\
\hline (1) average dietary energy supply adequacy & 1 & & & \\
(2) average value of food production per capita & 0.4373 & 1 & & \\
(3) access to improved water sources & 0.6071 & 0.4701 & 1 & \\
\hline (4) access to improved sanitation facilities & 0.5873 & 0.5169 & 0.8673 & 1 \\
\hline
\end{tabular}

Source: authors' calculations

The number of principal components is chosen based on two criteria. It is chosen according to (1) the cumulative variance of which at least 60 to $70 \%$ of the total information is explained and (2) the Kaiser criterion (Kaiser, 1960) which is used to keep the principal components that have an eigenvalue more than one.

Table 3: Total variance of principal components

\begin{tabular}{|c|c|c|c|}
\hline Component & Eigenvalue & Proportion of information & Cumulative of information \\
\hline PC1 & 2.61424 & $65.36 \%$ & $65.36 \%$ \\
\hline PC2 & 0.748148 & $18.70 \%$ & $84.06 \%$ \\
\hline PC3 & 0.537943 & $13.45 \%$ & $97.51 \%$ \\
\hline PC4 & 0.0996734 & $2.49 \%$ & $100 \%$ \\
\hline
\end{tabular}

Source: authors' calculations

The results in Table 3 show that the choice of the first component (PC1) is most appropriate because $65 \%$ of the total information is accounted by it. In addition, its eigenvalue is greater than one.

Table 4: the eigenvectors of each component.

\begin{tabular}{|l|c|c|c|c|}
\cline { 2 - 5 } \multicolumn{1}{c|}{} & PC1 & PC2 & PC3 & PC3 \\
\hline average dietary energy supply adequacy & 0.3766 & 0.9037 & -0.1968 & -0.0524 \\
\hline average value of food production per capita & 0.4983 & -0.0130 & 0.8532 & 0.1536 \\
\hline access to improved water sources & 0.5453 & -0.2853 & -0.4405 & 0.6535 \\
\hline access to improved sanitation facilities & 0.5589 & -0.3190 & -0.1982 & -0.7393 \\
\hline \multicolumn{2}{|c}{ Source: authors' calculations }
\end{tabular}


Since we have choose the first component, then we choose the first eigenvector from Table 4.

For a given year, multiplying each indicator by the square of the coefficient of the first eigenvector that corresponds to it, leads to a score. In turn, this score is our composite indicator and can be decomposed as follow:

$$
\begin{aligned}
\text { FSI }= & 0.137 \times \text { average dietary energy supply adequacy } \\
& +0.229 \times \text { average value of food production per capita } \\
& +0.303 \times \text { access to improved water sources } \\
& +0.331 \times \text { access to improved sanitation facilities }
\end{aligned}
$$

\subsubsection{Estimated model}

We estimated two equations. However, the specific effect on the estimation can be fixed or random. To avoid this problem, we used the specification of Hausman (1978). The Hausman test's null hypothesis is that the preferred model is random effects and the alternative is fixed effects, and the result suggested the fixed effects model. To find a way around the heteroscedasticity and autocorrelation, we follow Mihalache-O'Keef and Li (2011) and we use Huber-White robust standard error, clustered over countries.

As an initial step, we test the relationship between sectoral FDI and food security (equation

2). We estimate a fixed effect model as follow:

$$
\begin{aligned}
& F S I_{i t}=\alpha_{0}+\alpha_{1} F D I_{-} a g r i_{i t}+\alpha_{2} F D I_{-} \text {minig }_{i t} \\
& +\alpha_{3} F D I_{-} \text {secondary } y_{i t}+\alpha_{4} F D I_{-} \text {tertiary } y_{i t} \\
& +\alpha_{s} \ln \_ \text {prodagr } r_{i t}+\alpha_{G} \text { Openness }_{i t} \\
& +\alpha_{7} L r_{-} G D P_{-} \text {percopilu }{ }_{i t}+\alpha_{8} G v v_{-} e x p_{i t}+\alpha_{c} p u l i t y 2_{i t} \\
& +\gamma_{i} F E_{i}+\delta_{\iota} F E_{\iota}+\varepsilon_{i l}
\end{aligned}
$$

Where $i$ and $t$ refer to countries and years, respectively; $\alpha_{k}$ are the estimated coefficients and $\varepsilon_{i t}$ is the error term. FDI_agri, FDI_mining,FDI_secondary,FDI_tertiary represent 
agricultural, mining, secondary and tertiary foreign direct investments respectively, ln_prodagr is the logarithm of agricultural production value, Openness is the trade openness, Ln_GDP_percupilu is the logarithm of GDP per capita, Guv_exp is the annual percentage growth of general government final consumption expenditure and Polity 2 is the political regime. $F E_{i}$ are the country fixed effects and $F E_{t}$ represent time fixed effects.

In a second step, we consider the determinant of the agricultural production as a fixed effect model. Empirically, the agricultural production is widely treated by the estimation of CobbDouglas production function or a translog production function. Nevertheless, the purpose of our analysis has no interest to the partial elasticities of inputs variables or the exam of the inputs substitution, so a simple agricultural production can be used in our case. Further, the Cobb-Douglas agricultural production function (Cobb and Douglas, 1928) is largely used in the economic literature without a theoretical framework. Some authors have added other factors to explain the agricultural production. e.g. to investigate the effects of infrastructure, investments in agricultural research and education (Antle, 1983), to test the effects of transportation infrastructure and electricity on the agricultural production (Felloni et al., 2001), to examine the effect of governance quality (Lio and Liu, 2008) and to check the impact of climatic change on the agricultural production (Barrios et al., 2008).

The equation of the agricultural production is given by:

$$
\begin{aligned}
& \ln \_ \text {prodagr } r_{i t}=\beta_{0}+\beta_{1} \ln \_K_{i t}+\beta_{2} \ln \_L_{i t}+\beta_{3} \ln \_l a n d d_{i t} \\
& +\beta_{4} F D I_{-} a g r i_{i t}+\beta_{5} F D I_{-} \text {miningit } \\
& +\beta_{6} F D I_{-} \text {secondary } y_{i t}+\beta_{7} F D I_{-} \text {tertiary } y_{i t} \\
& +\beta_{R} F S I_{i t}+\beta_{\mathrm{q}} \text { Rural_pop pit. } \\
& +\gamma_{i} F E_{i}+\delta_{t} F E_{t}+\theta_{i t}
\end{aligned}
$$


Where $\beta_{i}$ are the estimated coefficients and $\theta_{i t}$ is the error term. $\ln \_K, \ln \_L$ and $\ln \_l a n d$ are the main inputs of the agricultural production and they represent the capital stock, labor force in agriculture and arable land respectively. FSI and Rural_pop are our food security index and the rural population growth respectively. As shown in the equation, we test for the impact of the sectoral FDI on the agricultural production. We integrate the composite indicator as a measure of individual energy intake and food availability because the lack of a person's energy nutrition with access to food, water and good sanitation reduces its ability to produce, which means that more workers are malnourished, less labor productivity is provided for agricultural production.

In a third step, we determine whether there is a relationship among variables between equations (2) and (3). Therefore, we tested for the endogeneity between the food security composite indicator and the agricultural production with the Durbin-Wu-Hausman endogeneity test ${ }^{8}$. The results suggest that endogeneity is significant. Thus, we estimated a simultaneous equations model with fixed effects (by year and by country) by using the threeleast squares (3SLS) method. The use of 3SLS method is validated by the Breusch-Pagan Lagrange Multiplier Diagonal Covariance Matrix Test under the null hypothesis that ordinary least square (OLS) method is consistent ${ }^{9}$.

\section{Estimation results' of the simultaneous equations models}

Table 5 reports the estimated results of simultaneous equations using 3SLS. First, we estimate the system three times. In Model 1, GDP per capita, government consumption and political regime are dropped from the food security's equation, and rural population growth is dropped from the production equation. In Model 2, we added the GDP per capita and finally in model 3 we include the rest of variables. All models contain time and country fixed effects. 
Table 5: estimation's results of simultaneous equations:

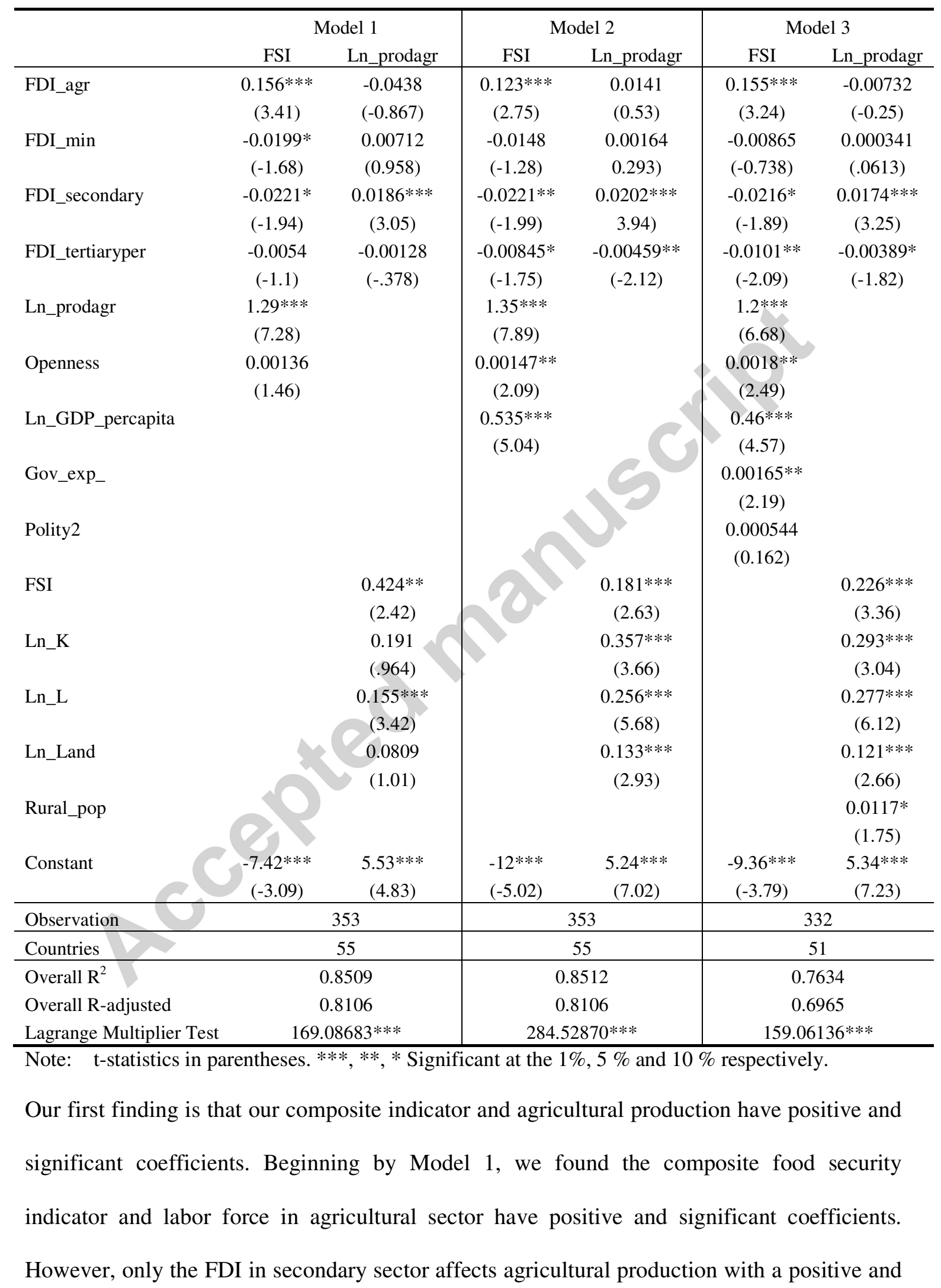


significant coefficient. This means that there is a spillover effect from manufacturing FDI on agricultural production, and therefore on food security. In the food security equation, only tertiary FDI and trade openness are not significant. FDI in agricultural and agricultural production affect positively the food security, however, FDI in mining and in secondary sectors have a negative impact significant at the level of $10 \%$.

After the addition of GDP per capita in Model 2, the trade openness becomes significant with the expected positive sign. FDI in tertiary sector also becomes significant but with negative sign. FDI in mining is no more a statistically significant factor. In the agricultural production's equation, the negative sign of FDI in tertiary sector and the positive signs of capital and arable land become significant.

Finally, in Model 3 we added the rest of variables and we have found that government expenditure is an important determinant to explain the improvement of food security and the rural population growth to explain the increase on agricultural production. Other variables have the expected signs. Finally, the coefficient associated to the political regime is positive but not significant.

In terms of growth, we interpret the increase of one independent variable while all other variable in the model are held constant. A $1 \%$ increase in the share of secondary FDI to GDP leads to $1.74 \%$ increase in agricultural production, while $1 \%$ in tertiary FDI declines the agricultural production about $0.4 \%$. A unit increase in food security indicator is associated with an average of $22 \%$ increase in agricultural production. At the same time, a $1 \%$ increase in the agricultural production and agricultural FDI, respectively, is associated with 0.155 and 0.012 units increase in the food security's composite indicator. However, an increase of $1 \%$ in secondary and tertiary FDI is followed by a decrease about 0.022 and 0.01 units, respectively.

In sum, our results give importance to agricultural FDI, agricultural production, trade openness and economic development in improving food availability and food utilization. In 
addition, our results highlight the adverse effects of FDI in secondary and tertiary sectors. These effects are lower comparing to the positive one from FDI in agriculture. This negative impact is a result of industrial development's pollution that affects environment and access to water, and thus the food availability and utilization. However, the positive effect from secondary FDI provides employment and spillover effect in term of technology transfer and know-how that are useful in improving agricultural production, the access to water and improved sanitation.

\section{Conclusion}

In recent decades, food security has taken more attention from policy makers in the developing world and FDI inflows became one of the main factors of development and growth in these countries. FDI inflows are expected to have some effects in DCs, specifically in food security context.

The sectoral FDI inflows' effects can shed new light on how the transmission takes place. In this paper, we treat the macroeconomic dimension of food security by the use of an unbalanced panel data of 55 developing countries for the period 1995-2009. The review of literature shows that the relation between FDI and food security is being discussed empirically as a direct relationship with the neglect of agriculture's role. Our work proposes an extension: we take into account the indirect effect through the agricultural production.

As shown in this paper, empirical research on the contribution of FDI in improving food security remains ambiguous and needs more work on it. Following a number of studies showing that FDI inflows affect food security, we found that the direct effects come from FDI in agriculture and the indirect effects come from FDI spillovers in the other economic sectors.

Our results have confirmed that FDI improves directly food availability and utilization by increasing food supplies, and access to water and improved sanitation. Food availability has a 
direct link with the agricultural production. If the DCs increase their agricultural production, the calorie supply and food production rise. This is an important step to decrease food prices. In addition, when the agricultural production increases, sellers will expand their radius of sale, which may be beneficial for people in less favorable areas of the nation.

Agricultural FDI contributes to the improvement of food security thanks to the increase in agricultural production, which is the main source of food. The benefits for agriculture due to agricultural FDI are in terms of know-how, R\&D and technology transfer. The secondary FDI creates employment, increases the individual's income, and therefore improves access to food. In contrast, negative spillovers from tertiary FDI on agricultural production and food security could be explained by the argument that FDI creates jobs in urban areas with higher wages which encourages workers in rural areas to migrate. Thus, the increase in demand in urban areas will increase the price paid by migrants and therefore reduces their access to food (Todaro, 1969; Evans and Timberlake, 1980; Mihalache-O'Keef and Li, 2011). Another negative effect from secondary on food availability and utilization can be explained by the pollution produced during manufacturing process.

Our findings have important implications. They give importance to FDI in increasing agricultural production and thus improving food security. However, we should not neglect that the host country must have the ability to absorb technology transfer and know-how. The discussion of the appropriate local policies needed for improving food security has to be deepened.

\section{References}

Adams S. Foreign direct investment, domestic investment, and economic growth in SubSaharan Africa. J Policy Model 2009; 31(6):939-949.

Akabzaa T, Darimani A. Impact of mining sector investment in Ghana: A study of the Tarkwa mining region. A Draft Report Prepared for the Structural Adjustment Participatory Review International Network. Washington, DC; 2001. 
Amirahmadi H, Wu W. Foreign Direct Investment in Developing Countries. J Dev Areas 1994; 28:167-190.

Antle J M. Infrastructure and Aggregate Agricultural Productivity: International Evidence. Econ Dev Cult Change 1983; 31(3): 609-619.

Barrios S, Ouattara B, Strobl E. The impact of climatic change on agricultural production: Is it different for Africa?. Food policy 2008; 3: 287-298.

Binswanger H, Yang M-C, Bowers A, Mundlak Y. On the determinants of cross-country aggregate agricultural supply. J Econometrics 1987; 36 (1-2): 111-131.

Breisinger C, von Rheenen T, Ringler C, Nin Pratt A, Minot N, Aragon C, et al. Food security and economic development in the Middle East and North Africa. IFPRI Discussion Paper 00985, May; 2010.

Bwalya SM. Foreign direct investment and technology spillovers: Evidence from panel data analysis of manufacturing firms in Zambia. J Dev Econ 2006; 81:514-526.

Cobb CW, Douglas PH. A Theory of Production. The Am Econ Rev 1928; 18(1):139-165.

Conforti P. New approaches to the measurement of food security. FAO Statistics Division. Communication presented at the 23rd African Commission on Agricultural Statistics, Morrocco; 2013.

De Haen H, Klasen S, Qaim M. What do we really know ? Metrics for food insecurity and undernutrition. Food Policy 2011; 36: 760-769.

Deolalikar AB. Nutrition and labor productivity in agriculture: estimates for rural south India. The Rev of Econ and Statistics 1988; 70 (3):406-413.

Diaz-Bonilla E, Thomas M, Robinson S, Cattaneo A. Food security and trade negotiations in the world trade organization: a cluster analysis of country groups. TMD Discussion paper 59, International Food Policy Research Institute. Washington, DC; 2000.

Diaz-Bonilla E, Thomas M, Robinson S. Trade, food security and the WTO Negotiations: some reflections on boxes and their contents. Chapter in Agricultural Trade and Poverty. Making Policy Analysis Count. OECD, Paris; 2003.

Dixon W, Boswell T. Dependency, Disarticulation, and Denominator Effects: Another Look at Foreign Capital Penetration. Am J of Sociol 1996; 102:543-562.

Djokoto JG. Effects of foreign direct investment inflows into agriculture on food security in Ghana. J of Econ and Sustain Dev 2012; 3(2):81-92.

Dries L, Swinnen JF. Foreign direct investment, vertical integration, and local suppliers: evidence from the polish dairy sector. World Dev 2004;32(9):1525-1544. 
Evans PB, Timberlake M. Dependence, inequality, and the growth of the tertiary: a comparative analysis of less developed countries. Am Sociol Rev 1980; 45(4):531-552.

FAO. Food energy-methods of analysis and conversion factors. FAO food and nutrition paper 77; 2003 Decembre.

FAO. The state of food insecurity in the world: eradicating world hunger - taking stock ten years after the World Food Summit. Rome; 2006a.

FAO. Food security. Policy Brief (2); 2006b June.

FAO. Declaration of the World Summit on food security. Rome; 2009 November.

FAO, WFP, IFAD. The State of Food Insecurity in the World 2012. Economic growth is necessary but not sufficient to accelerate reduction of hunger and malnutrition. Food and agriculture organization of the United nations. Rome; 2012.

FAO, IFAD, WFP. The State of Food Insecurity in the World 2013. The multiple dimensions of food security. Food and agriculture organization of the United nations. Rome; 2013.

Felloni F, Wahl T, Wandschneider P, Gilbert J. Infrastructure and agricultural production: Cross-country evidence and implications for China. TW-2001-103. Washington State University; 2001.

Firebaugh G. Growth effects of foreign and domestic investment. Am J of Sociol 1992; 98 (1):105-130.

Firebaugh G, Beck FD. Does economic growth benefit the masses? growth, dependence, and welfare in the Third World. Am Sociol Rev 1994; 59 (5):631-653.

Gentilini U, Webb P. How are we doing on poverty and hunger reduction? A new measure of country performance. Food policy 2008; 33 (6):521-532.

Gerlach A, Liu P. Resource-seeking foreign direct investments in Africa: A review of country case studies. FAO Commodity and trade policy research working paper 31; 2010.

Graham EH. Foreign direct investment in the world economy. IMF Working Paper WP/95/59; 1995.

Hallam D. International investment in developing country agriculture - issues and challenges. Food Secur 2011; 3 (S1):S91-S98.

Hausman JA. Specification Tests in Econometrics. Econometrica 1978; 46(6):1251-1271.

Headey D, Ecker O. Improving the Measurement of Food Security. IFPRI Discussion Paper 01225. International Food Policy Research Institute. Washington, DC; 2012.

Heo U, Hahm SD. The Political Economy of U.S. Direct Investment in East Asian NICs, 1966-2000, International Interactions: Empirical and Theoretical Research in International Relations 2007; 33(2):119-133. 
Jenkins JC, Scanlan, S. Food security in less developed countries, 1970-1990. Am. Sociol. Rev 2001; 66 (5):718-44.

Jensen, RT, Miller NH. A Revealed Preference Approach to Measuring Undernutrition and Poverty Using Calorie Shares. NBER Working Paper 16555. National Bureau of Economic Research, Cambridge, MA; 2010.

Kaiser HF. The application of electronic computers to factor analysis. Educ Psychol Meas 1960; 20:141-151.

Kumar N, Pradhan JP. FDI, externalities, and economic growth in developing countries: Some empirical explorations and implications for WTO negotiations on investment. RIS Discussion Paper No. 27/2002; 2002.

Li X, Liu X. Foreign direct investment and economic growth: An increasingly endogenous relationship. World Dev 2005; 33 (3):393-407.

Lio M, Liu MC. Governance and agricultural productivity: A cross-national analysis. Food Policy 2008; 33 (6):504-512.

Liu Z. Foreign direct investment and technology spillovers: theory and evidence. J of Dev Econ 2008; 85:176-193.

Liu P. Impacts of foreign agricultural investment on developing countries : evidence from case studies. FAO Commodity and Trade Policy, Research working paper 2014, 47.

Masset E. A review of hunger indices and methods to monitor country commiment to fighting hunger. Food Policy 2011; 36:102-108.

Mihalache-O‘Keef A, Li Q. Modernization vs. Dependency revisited: Effects of foreign direct investment on food security in less developed countries. Int Stud Q 2011; 55 (1):71-93.

Mundlak Y, Larson DF, Butzer R. Rethinking within and between Regressions: The Case of Agricultural Production Functions. Annales d'Economie et de Statistique 1999; (55/56):475501.

Scanlan SJ, Jenkins JC. Military Power and Food Security: A Cross-National Analysis of Less-Developed Countries, 1970-1990. Int Stud Q 2001; 45:159-187.

Sen A. Development as freedom. New York: Anchor Books; 1999.

Shehata, EAE. LMCOVREG3: Stata Module to Compute Breusch-Pagan Lagrange Multiplier Diagonal Covariance Matrix Test after (3SLS-SURE) Regressions; 2012.

Strauss J. Does better nutrition raise farm productivity. J of Polit Econ 1986; 94 (2):297-320.

Tambunan T. The impact of foreign direct investment on poverty reduction: a survey of literature and a temporary finding from Indonesia. Paper presented at consultative meeting on 
Foreign Direct Investment and Policy Changes: Areas for New Research, United Nations Conference Centre, Bangkok, Thailand. March; 2005.

Timmer CP. Reflections on food crises past. Food Policy 2010; 35 (1):1-11.

Todaro MP. A model of labor migration and urban unemployment in less developed countries. The Am Econ Rev 1969; 59 (1):138-148.

Tondl G, Fornero J. Sectoral productivity and spillover effects of FDI in Latin America. FIW Working Paper series 053; 2010.

Tweeten L. The Economics of Global Food Security. Appl Econ Perspect Pol 1999; 21 (2): 473-488.

UNCTAD. World Investment Report. United Nations Conference on Trade and Development, New York; 2013.

United Nations. United Nations Millennium Declaration. A/Res/55/2, New York; 2000.

Verardi V. Robust principal component analysis in Stata. United Kingdom Stata Users' Group Meetings 2009 02, Stata Users Group; 2009.

$\mathrm{Vu} \mathrm{TB}$, Noy I. Sectoral analysis of foreign direct investment and growth in the developed countries. J Int Finan Markets, Inst Money 2009; 19(2):402-413.

Wimberley D. Transnational corporate investment and food consumption in the Third World: A cross-national analysis. Rural Sociol 1991; 56 (3):406-431.

Wimberley D, Bello R. Effects of foreign investment, exports, and economic growth on Third World food consumption. Soc Forces 1992; 70 (4):895-921.

World Bank. Poverty and hunger: issues and options for food security in developing countries. Washington, DC; 1986.

World Bank, Agriculture for development. World Development Report 2008. 


\section{Appendix}

Table A1: List of countries

\begin{tabular}{|c|c|c|c|c|c|}
\hline 1 & Albania & \begin{tabular}{|l|l|}
12 & Colombia \\
\end{tabular} & \begin{tabular}{|l|l|}
23 & India \\
\end{tabular} & \begin{tabular}{|l|l|}
34 & Mauritius \\
\end{tabular} & \begin{tabular}{|l|l|}
45 & Russian Federation \\
\end{tabular} \\
\hline 2 & Argentina & 13 Costa Rica & 24 Indonesia & 35 Mexico & 46 Saudi Arabia \\
\hline 3 & Armenia & \begin{tabular}{|l|l|}
14 & Croatia \\
\end{tabular} & \begin{tabular}{|l|l|}
25 & Kazakhstan \\
\end{tabular} & \begin{tabular}{|l|l}
36 & Moldova \\
\end{tabular} & \begin{tabular}{|l|l|}
47 & Thailand \\
\end{tabular} \\
\hline 4 & Bangladesh & \begin{tabular}{|l|l|}
15 & Ecuador \\
\end{tabular} & \begin{tabular}{|l|l|}
26 & Kyrgyz Republic \\
\end{tabular} & \begin{tabular}{|l|l|}
37 & Morocco \\
\end{tabular} & \begin{tabular}{|l|l|}
48 & Tunisia \\
\end{tabular} \\
\hline 5 & Bolivia & \begin{tabular}{|l|l|}
16 & Egypt \\
\end{tabular} & \begin{tabular}{|l|l|}
27 & Lao PDR \\
\end{tabular} & 38 Mozambique & \begin{tabular}{|l|l|}
49 & Turkey \\
\end{tabular} \\
\hline 6 & Bosnia and Herzegovina & \begin{tabular}{|l|l|}
17 & El Salvador \\
\end{tabular} & \begin{tabular}{|l|l|}
28 & Latvia \\
\end{tabular} & \begin{tabular}{|l|l|}
39 & Nicaragua \\
\end{tabular} & 50 Ukraine \\
\hline 7 & Brazil & \begin{tabular}{|l|l|}
18 & Ethiopia \\
\end{tabular} & 29 Lithuania & 40 Pakistan & \begin{tabular}{|l|l}
51 & Tanzania \\
\end{tabular} \\
\hline 8 & Bulgaria & \begin{tabular}{|l|l|}
19 & Fiji \\
\end{tabular} & \begin{tabular}{|l|l|}
30 & Macedonia \\
\end{tabular} & \begin{tabular}{l|l}
41 & Panama \\
\end{tabular} & 52 Uruguay \\
\hline & Cambodia & 20 Guyana & 31 Madagascar & \begin{tabular}{|l|l|}
42 & Paraguay \\
\end{tabular} & 53 Vanuatu \\
\hline & Chile & 21 Honduras & \begin{tabular}{|l|l|}
32 & Malawi \\
\end{tabular} & \begin{tabular}{|l|l|}
43 & Peru \\
\end{tabular} & 54 Zambia \\
\hline & China & \begin{tabular}{|l|l|}
22 & Hungary \\
\end{tabular} & \begin{tabular}{|l|l|}
33 & Malaysia \\
\end{tabular} & \begin{tabular}{l|l}
44 & Philippines \\
\end{tabular} & 55 Romania \\
\hline
\end{tabular}

Table A2: Variables definitions

\begin{tabular}{|c|c|c|}
\hline Variable & Definition & Source \\
\hline $\begin{array}{l}\text { average dietary energy } \\
\text { supply adequacy }\end{array}$ & $\begin{array}{l}\text { the dietary energy supply as a percentage of the average } \\
\text { dietary energy requirement in each country }\end{array}$ & \multirow{4}{*}{ FAOSTAT } \\
\hline $\begin{array}{l}\text { average value of food } \\
\text { production per capita }\end{array}$ & $\begin{array}{l}\text { The total value of annual food poduction, in International } \\
\text { Dollars divided by the total population }\end{array}$ & \\
\hline $\begin{array}{l}\text { access to improved water } \\
\text { sources }\end{array}$ & $\begin{array}{l}\text { The percentage of the population with access to an } \\
\text { improved water source }\end{array}$ & \\
\hline $\begin{array}{l}\text { access to improved } \\
\text { sanitation facilities }\end{array}$ & $\begin{array}{l}\text { the percentage of the population with access to improved } \\
\text { sanitation facilities }\end{array}$ & \\
\hline FSI & The composite indicator of food security & Authors' calculation \\
\hline FDI_agri & $\begin{array}{l}\text { Agriculture, hunting, forestry and fishing FDI inflows as } \\
\text { share of GDP }(\%)\end{array}$ & \multirow{4}{*}{$\begin{array}{l}\text { National source and } \\
\text { UNCTAD }\end{array}$} \\
\hline FDI_mining & $\begin{array}{l}\text { Mining, quarrying, oil and gas FDI inflows as share of } \\
\text { GDP }(\%)\end{array}$ & \\
\hline FDI_secondary & Secondary FDI inflows as share of GDP (\%) & \\
\hline FDI_tertiary & Tertiary FDI inflows as share of GDP (\%) & \\
\hline Openness & $\begin{array}{l}\text { The sum of exports and imports of goods and services as } \\
\text { a share of GDP }\end{array}$ & $\begin{array}{l}\text { World development } \\
\text { indicator (WDI) }\end{array}$ \\
\hline Ln_GDP_percapita & $\begin{array}{l}\text { The logarithm GDP per capita million at constant } 2000 \\
\text { prices }\end{array}$ & WDI \\
\hline Gov_exp & $\begin{array}{l}\text { The annual growth of the general government final } \\
\text { consumption expenditure }\end{array}$ & WDI \\
\hline polity2 & Political regime & Polity IV \\
\hline Ln_prodagr & $\begin{array}{l}\text { The logarithm of agricultural production, measured by } \\
\text { the value of agricultural production in millions of dollars } \\
\text { at constant } 2005 \text { prices }\end{array}$ & FAOSTAT \\
\hline $\mathrm{Ln} \_\mathrm{K}$ & $\begin{array}{l}\text { The logarithm of capital stock in agriculture millions at } \\
\text { constant } 2005 \text { price }\end{array}$ & FAOSTAT \\
\hline Ln_L & $\begin{array}{l}\text { The logarithm of labor force in agriculture in thousand } \\
\text { people }\end{array}$ & UNCTAD \\
\hline Ln_land & The Logarithm of arable land in hectares & WDI \\
\hline Rural_pop & The annual growth of the rural population & WDI \\
\hline
\end{tabular}


Table A3: Summary statistics

\begin{tabular}{|l|c|c|c|c|c|}
\hline \multicolumn{1}{|c|}{ Variables } & Observation & Mean & Std. Dev. & Min & Max \\
\hline average dietary energy supply adequacy & 930 & 114.972 & 14.2059 & 72 & 163 \\
\hline average value of food production per capita & 930 & 275.6398 & 156.8022 & 44 & 1006 \\
\hline access to improved water sources & 914 & 84.52024 & 16.22708 & 20 & 100 \\
\hline access to improved sanitation facilities & 920 & 69.48891 & 26.29902 & 3 & 100 \\
\hline FSI & 892 & 9.85592 & 2.03677 & 3.15264 & 14.41675 \\
\hline FDI_agri & 492 & 0.1196823 & 0.3424275 & -.646552 & 2.846407 \\
\hline FDI_mining & 445 & 0.5497982 & 1.31659 & -1.55195 & 15.9483 \\
\hline FDI_secondary & 675 & 0.8564049 & 0.9890689 & -1.784948 & 11.48758 \\
\hline FDI_tertiary & 688 & 2.08507 & 2.750672 & -2.125577 & 32.1708 \\
\hline Ln_prodagr & 945 & 15.08674 & 1.807903 & 9.421168 & 20.07799 \\
\hline Openness & 937 & 80.79348 & 36.9255 & 14.93285 & 220.4068 \\
\hline Ln_GDP_percapita & 937 & 7.363384 & 1.082748 & 4.735071 & 9.875359 \\
\hline Gov_exp & 850 & 4.481702 & 9.895243 & -57.81461 & 83.22173 \\
\hline polity2 & 900 & 4.534444 & 5.716702 & -10 & 10 \\
\hline Ln_K & 819 & 9.330377 & 1.78528 & 3.67097 & 13.23481 \\
\hline Ln_L & 945 & 7.142199 & 2.211494 & 0 & 13.13469 \\
\hline Ln_land & 945 & 14.7218 & 2.028449 & 7.600903 & 18.90752 \\
\hline rural_pop & 945 & 0.3604173 & 1.242269 & -4.423409 & 3.482749 \\
\hline
\end{tabular}




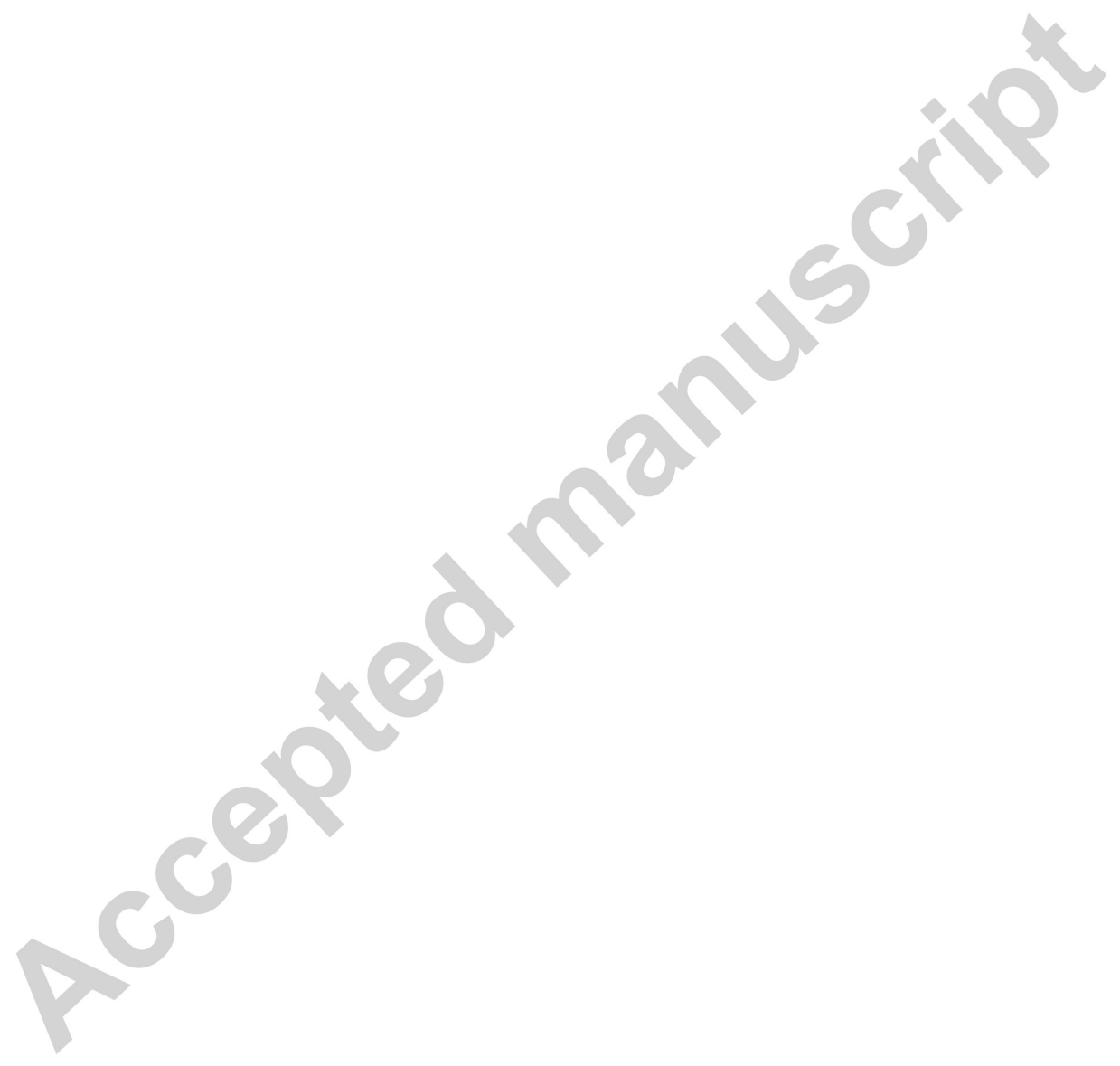



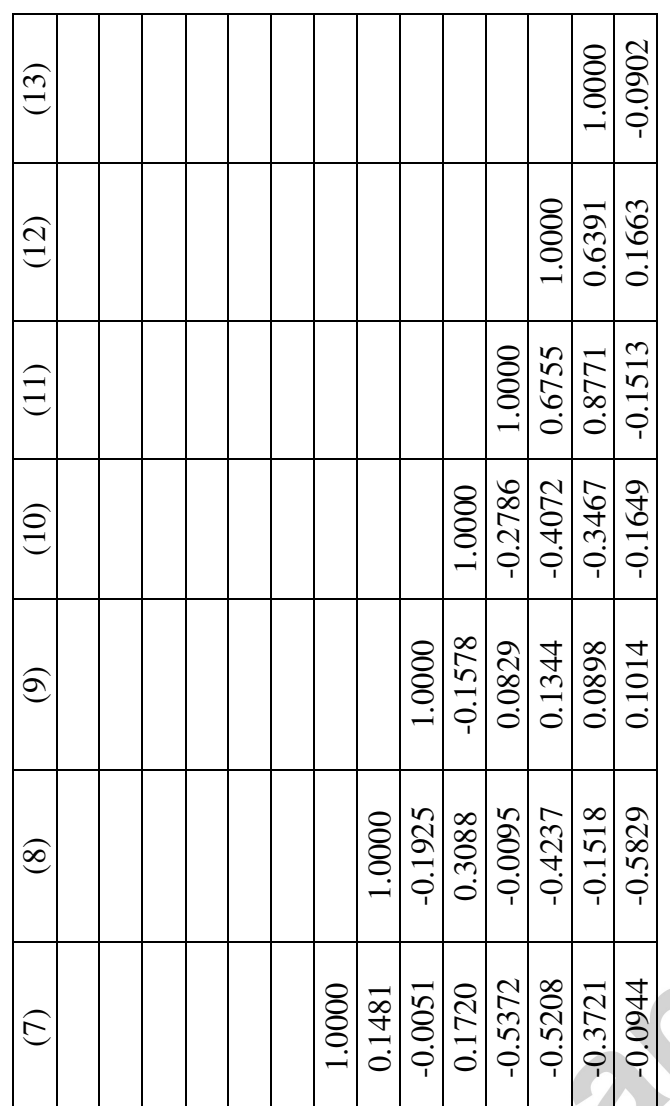

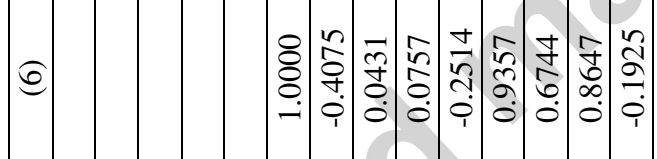

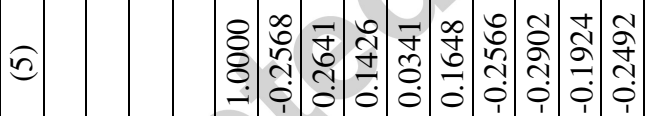

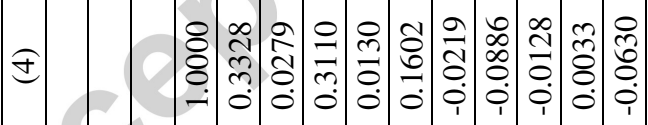

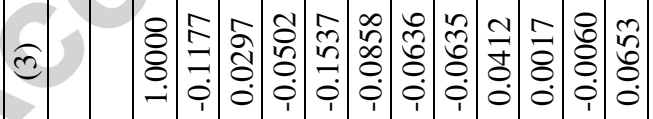

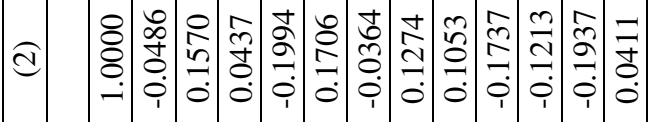

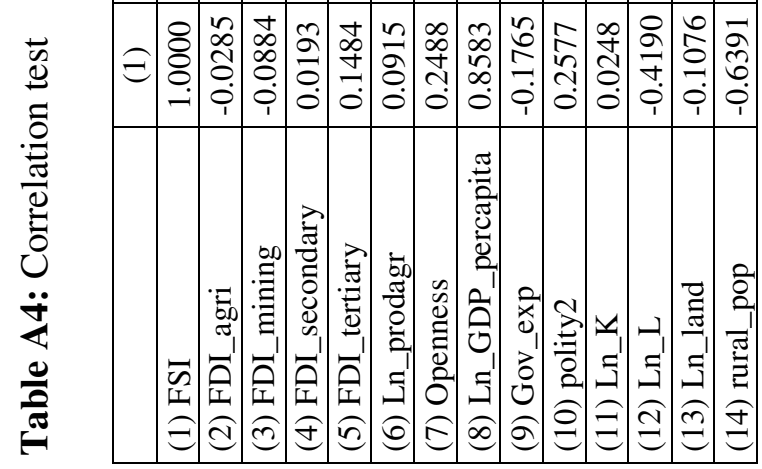




\section{Footnotes}

1- Liu (2014) shows that agricultural investments can generate a wide range of developmental benefits but these benefits are not expected to arise automatically. The case studies suggest that the disadvantages of large-scale land acquisitions may overweight the few benefits to the local community according to the local rights and the quality of governance in particular.

2- For more information about the various indices and their limits, see De Haen et al. (2011) and Masset (2011).

3- At the nutritional level, one grams of protein provide four calories; one grams of carbohydrate also provides four calories, and one grams of fats provides nine calories (FAO, 2003).

4- In this paper, we regress the agricultural production value (not the value added of primary sector). So for a more accurate result, we use the agricultural FDI and mining FDI separately.

5- The estimation's result can be more specific with data for FDI in agri-food industry, but data isn't available for all countries and it has low number of observation so we used the aggregated FDI in secondary sector.

6- See « Polity IV Users' Manual » viewed at : http://www.systemicpeace.org/inscr/p4manualv2012.pdf

7- The use of PCA technic in food security indicators was suggested by Conforti (2013) from FAO STATISTIC DIVISION at the 23rd African Commission on Agricultural Statistics in Morrocco.

8- The test is explained by Li and Liu (2005) where thy test the endogeneity between FDI and economic growth.

9- We perform this test by the Stata command of Shehata (2012). 